\title{
Oligomannuronate prevents mitochondrial dysfunction induced by IAPP in RINm5F islet cells by inhibition of JNK activation and cell apoptosis
}

Xi Liu ${ }^{1,2}$, Qiong Li ${ }^{1,2}$, Xiaolei Cheng ${ }^{3}$, Zhichun Liu ${ }^{1,2}$, Xiaoliang Zhao ${ }^{4}$, Shuai Zhang ${ }^{1,2}$, Guangli Yu ${ }^{1,2}$, Xia Zhao ${ }^{1,2^{*}}$ and Jiejie Hao ${ }^{1,2^{*}}$

\begin{abstract}
Background: Oligomannuronates $(\mathrm{OM})$ are natural products from alginate that is frequently used as food supplement. The aim of this study was to investigate the in vitro protective effects of OM on RINm5F cells against human Islet amyloid polypeptide (IAPP) induced mitochondrial dysfunction, as well as the underlying mechanisms.
\end{abstract}

Methods: In the present study, we obtained several kinds of OM with different molecular masses, and then we used RINm5F cells as a model to elucidate the involvement of JNK signal pathway in hIAPP-induced mitochondrial dysfunction in pancreatic beta cells, and the protective effects of $\mathrm{OM}$ are associated with its ability to attenuate the mitochondrial dysfunction.

Results: Our results demonstrated that human IAPP induced mitochondrial dysfunction, as evidence by loss of $\triangle \psi_{\mathrm{m}}$ and ATP content, and decrease in oxygen consumption and complex activities, was accompanied by JNK activation, changes in the expressions of $\mathrm{BCl}-2$ and Bax proteins, release of cytochrome $\mathrm{c}$ (Cyto-c) and apoptosis inducing factor (AIF) from mitochondria into cytosol. Interestingly, the human IAPP induced damage in RINm5F cells were effectively restored by co-treatment of OM. Moreover, JNK activation was required for the OM mediated changes in RINm5F cells.

Conclusions: OM prevented mitochondrial dysfunction induced by human IAPP in RINm5F islet cells through JNK dependent signaling pathways.

Keywords: Oligomannuronate, Type 2 diabetes, Islet amyloid polypeptide, JNK activation, Mitochondrial dysfunction, RINm5F cells

\section{Background}

Islet formation is a hallmark of type 2 diabetes occurring in most patients $[1,2]$, which is associated with decrease beta cell function and mass. Islet amyloid polypeptide (IAPP) is a major component of the amyloid deposits.

\footnotetext{
*Correspondence: zhaoxia@ouc.edu.cn; 2009haojie@ouc.edu.cn

${ }^{+}$Xi Liu and Qiong Li are co-first authors

${ }^{2}$ School of Medicine and Pharmacy, Ocean University of China, Qingdao 266003, China

Full list of author information is available at the end of the article
}

Human IAPP (hIAPP) is a peptide hormone composed of natural unstructured 37 residues that are commonly stored and secreted from the beta cell secretory granules of islets [1,3]. hIAPP contains critical structure for $\beta$-pleated sheet formation, which has propensity to form amyloid fibrils [4]. Gradual loss of insulin-producing islet beta cell mass in type 2 diabetic patients leads to increased islet amyloid deposits. Moreover, synthetic hIAPP fibrils and oligomers induced apoptosis in human or rat islet beta cells. In the hIAPP transgenic mouse model, hyperglycemia causes an increase in amyloid 
formation and a decrease in beta cell mass [5, 6]. Some researches indicate that the cytotoxicity of hIAPP according with endoplasmic reticulum stress, oxidative stress and mitochondrial dysfunction $[5,7]$.

It is well known that mitochondria have important functions in storing energy, regulating metabolism and cell growth pathways. Previous reports suggested that metabolic dysregulation and insulin secretory failure might be due to mitochondrial dysfunction in the pathogenesis of type 2 diabetes $[8,9]$. Moreover, mitochondria participate in the control of islet beta cell mass. Several reports demonstrated that apoptosis due to mitochondrial dysfunction was especially apparent in pancreatic beta cells $[7,10,11]$. Besides, another central pathway to regulate beta cell growth and apoptosis is the c-Jun $\mathrm{N}$-terminal protein kinase (JNK) pathway, which is activated in response to several stress stimuli, such as high glucose [12], ER stress [13, 14], and hIAPP [15-17]. Recent investigations on the interplay between JNK pathway and mitochondria is focused on, and results revealed that the functional interactions of JNK and mitochondria is complicated and remains to be built up [18-22], and moreover, the link between mitochondria function and JNK pathway in hIAPP-induced beta cell has not been reported.

Alginate, is a kind of acidic linear polysaccharide which consists of $\beta$-D-mannuronic acid and $\alpha$-L-guluronic acid [23]. Alginate oligosaccharide and their derivatives have been widely used in the food, cosmetics and pharmaceutical industries $[23,24]$. Recently, low molecular weight alginate has attracted lots of scientific interest due to their bioactivity of plant growth promotion [25], antitumor [26, 27], and neuron protection [28, 29]. Moreover, some alginate-derived OM showed an outstanding activity in glucose and lipid metabolism in $\mathrm{C} 2 \mathrm{C} 12$ skeletal muscle cells [30]. But there is no detailed information about the effects of OM on the pancreatic beta cells, no mention the comparative research in the relationship between the effects and OM with different molecular masses.

In the present study, we obtained several kinds of $\mathrm{OM}$ with different molecular masses, and then we used RINm5F cells as a model to elucidate the involvement of JNK signal pathway in hIAPP-induced mitochondrial dysfunction in pancreatic beta cells, and the protective effects of $\mathrm{OM}$ are associated with its ability to attenuate the mitochondrial dysfunction.

\section{Materials and methods}

\section{Materials and reagents}

Polymannuronic acid (M-block) with weight-average molecular weight $(\mathrm{Mw})$ of $21.0 \mathrm{kDa}$ was provided by Lantai Pharmaceutical Company (Qingdao, China).
RPM1640 medium, fetal bovine serum (FBS), penicillin, and streptomycin were purchased from Gibco (Grand Island, NY). Anti-phospho JNK (\#4668), anti-Cyto c (\#4280), anti-Bax (\#5023), anti-Bcl 2 (\#3498) and antiAIF (\#5318) were from Cell Signaling Technology; other chemicals that were not specifically mentioned here were purchased from Sigma.

\section{Preparation of OMs and analytical methods}

M-block was dissolved with dilute ammonia water in a Pyrex tube $(\mathrm{pH}=5)$ and hydrolyzed under microwave irradiation (1600 W, CEM corporation, Matthews, North Carolina, USA) at different conditions as previously described [31]. Four OMs were prepared at $2 \%(\mathrm{w} / \mathrm{v})$, $130{ }^{\circ} \mathrm{C}, 20 \mathrm{~min} ; 5 \%(\mathrm{w} / \mathrm{v}), 120{ }^{\circ} \mathrm{C}, 5 \mathrm{~min} ; 5 \%(\mathrm{w} / \mathrm{v}), 100$ ${ }^{\circ} \mathrm{C}, 20 \mathrm{~min}$ and $8 \%(\mathrm{w} / \mathrm{v}), 100{ }^{\circ} \mathrm{C}, 10 \mathrm{~min}$,respectively. The hydrolysates were decolorized by activated carbon and filtered by $0.22 \mu \mathrm{m}$ cellulose membrane, then freezedried to obtain OMs with different $M \mathrm{w}$ compounds.

The relative weight-averaged molecular weight $(\mathrm{Mw})$ of OMs made by microwave degradation were determined by high performance gel permeation chromatography combined with multi-angle laser light scattering (HPGPC-MALLS) on an Agilent 1260 chromatographic instrument. The OMs was dissolved in $0.1 \mathrm{~mol} / \mathrm{L} \mathrm{Na}_{2} \mathrm{SO}_{4}$ elution solvent at a concentration of $5 \mathrm{mg} / \mathrm{mL}$. Then 100 $\mu \mathrm{L}$ of the sample was applied to a TSK gel G3000PWXL column $(7.8 \mathrm{~mm} \times 300 \mathrm{~mm}$, Tosoh, Japan) with a flow rate of $0.6 \mathrm{~mL} / \mathrm{min}$. The temperature of column was maintained at $35{ }^{\circ} \mathrm{C}$ and the signal was detected by G1362A refractive index detector (RID) and MALLS (Dawn Heleos-II, Wyatt technologies, USA). The Mw of each sample was calculated by Astra 5.3.4.20 software.

The total sugar content of OMs was determined according to the method of Dubois et al. using D-glucuronic acid as the standard [32]. The amount of uronic acids was determined using the carbazole reaction method described by Bitter and Muir, and D-glucuronic acid was used as the standard [33].

\section{Infrared spectral and NMR analysis}

For FTIR analysis, the dried samples (1-2 mg) were mixed with $100 \mathrm{mg}$ dried $\mathrm{KBr}$ and pressed to a transparent pellet and then analyzed with a Nicolet Nexus 470 FTIR spectrometer (Thermo Electron) under dry air at $400-4000 \mathrm{~cm}^{-1}$. And For ${ }^{1} \mathrm{H}-\mathrm{NMR}$ and ${ }^{13} \mathrm{C}-\mathrm{NMR}$ analyses, the sample was dissolved in $\mathrm{D}_{2} \mathrm{O}$ (99.96\%) and freeze-dried twice to replace all exchangeable protons with deuterium. Spectra were acquired at $25{ }^{\circ} \mathrm{C}$ using JNM-ECP $600 \mathrm{MHz}$ equipment (JNM-ECP 600, Jeol, Japan). Chemical shift values were calibrated using acetone- $d 6$ as an internal standard. The data were processed using the MestReNova software. 


\section{Cell culture and treatments}

RINm5F cells, from American Type Culture collection (ATCC), were cultured in RPMI 1640 medium supplemented with $10 \%(\mathrm{v} / \mathrm{v})$ fetal bovine serum, $2 \mathrm{mM}$ L-glutamine, $100 \mathrm{U} / \mathrm{mL}$ penicillin, and $100 \mu \mathrm{g} / \mathrm{mL}$ streptomycin, at $37{ }^{\circ} \mathrm{C}$ in a humidified $\left(5 \% \mathrm{CO}_{2}, 95 \%\right.$ air $)$ atmosphere. All experiments were performed using cells between passages 21 and 30 .

For peptide treatment, lyophilized hIAPP (Calbiochem) was dissolved in $80 \%$ hexafluoroisopropanol (HFIP, Sigma-Aldrich) to a concentration of $521 \mu \mathrm{M}$, filtered over $0.2 \mu \mathrm{m}$ filters (Millipore), and stored at -20 ${ }^{\circ} \mathrm{C}$ until use. hIAPP aggregates were prepared by diluting hIAPP to $6.5 \mu \mathrm{M}$ in $10 \mathrm{mM}$ phosphate buffer, pH7.4, $1.0 \%$ HFIP, and by incubating the mixture at $25^{\circ} \mathrm{C}$ for $30 \mathrm{~min}$ before use.

Cells were pre-incubated with various concentrations of OMs for $48 \mathrm{~h}$, and then remove the OMs and change for the fresh medium. Meanwhile, the hIAPP aggregates solution was applied to cultured cells at a final concentration of $250 \mathrm{nM}$ for $24 \mathrm{~h}$.

\section{MTT assay}

RINm5F cells seeded in 96-well microplate were cultured at $37{ }^{\circ} \mathrm{C}$ in a humidified atmosphere for $72 \mathrm{~h}$, and then the cells were exposed to different treatments for different periods of time. After incubation, $20 \mu \mathrm{L} /$ well of MTT solution (5 $\mathrm{mg} / \mathrm{mL}$ in PBS buffer) was added and incubated for $4 \mathrm{~h}$. The medium was aspirated and replaced with DMSO to dissolve the formazan salt. The color intensity of the formazan solution, which reflects the cell growth condition, was measured at $570 \mathrm{~nm}$ using a microplate spectrophotometer.

\section{Measurement of mitochondrial membrane potential (MMP, $\Delta \Psi \mathrm{m})$}

Determination of $\Delta \Psi \mathrm{m}$ was carried out using the ratiometric dye JC-1 (5,5',6, $6^{\prime}$ - tetrachloro-1, $1^{\prime}, 3,3^{\prime}$-tetraethylbenzimidazolyl-carbocyanine iodide), which is a dual emission potential-sensitive probe [34]. Freshly prepared cells were incubated with $10 \mu \mathrm{g} / \mathrm{mL}$ of JC-1 for $30 \mathrm{~min}$ at $37{ }^{\circ} \mathrm{C}$, washed twice with PBS, and then analyzed by a dual-wavelength/double-beam recording spectrophotometer (Ex490nm, Em530 and Ex525nm, Em590). $\Delta \Psi \mathrm{m}=$ A525-A590/A490-A530 (Flex Station384, Molecular Devices, USA).

\section{Detection of intracellular Reactive Oxygen Species (ROS)}

The production of cellular ROS was measured by $2^{\prime}, 7^{\prime}$-dichlorofluorescin diacetate (DCFH2-DA) oxidation [35]. Freshly prepared cells were incubated with $2 \mu \mathrm{M}$ DCFH2-DA for $30 \mathrm{~min}$ at $37 \mathrm{C}$, and then washed with
PBS buffer, and the fluorescence was measured at $485 \mathrm{~nm}$ excitation and $535 \mathrm{~nm}$ emission recording spectrophotometer (Flex Station 384, Molecular Devices, USA).

\section{Determination of ATP content}

The intracellular ATP content was determined using a bioluminescence somatic cell assay kit according to the manufacturer's instructions. After various treatments, cells were lysed by $0.5 \%$ Triton X-100 in $100 \mathrm{mM}$ glycine buffer, pH 7.4. Intracellular ATP levels were assayed with an ATP bio-luminescence assay kit (Sigma) based on the luciferase-catalyzed oxidation of D-luciferin [36]. The number of viable cells was counted with trypan blue using a hemacytometer. ATP level was expressed as femtomoles per cell.

\section{Mitochondrial respiration}

Oxygen consumption by intact cells was measured as described [37]. After treatment, the islet beta cells were washed in KRH buffer plus 1\% BSA. Cells from each condition were divided into triplicate aliquots and measured in a BD Oxygen Biosensor System plate (BD Biosciences). Plates were sealed and 'read' on a fluorescence spectrometer (Molecular Probes, Eugene, OR, USA) at $1 \mathrm{~min}$ intervals for $60 \mathrm{~min}$ at an excitation wavelength of 485 $\mathrm{nm}$ and emission wavelength of $630 \mathrm{~nm}$. We have used $5 \times 10^{5}$ cells in the assay. The oxygen consumption rate of cells generally follows Michaelis-Menten kinetics with respect to oxygen concentration. $\mathrm{V}_{\max }$ is the maximum consumption rate.

\section{Activity of mitochondrial complexes I, II and III}

Adipocytes were cultured in $100 \mathrm{~mm}$ plates and washed in PBS. Following addition of trypsin, the cells were pelleted by centrifugation at $300 \mathrm{~g}$ for $5 \mathrm{~min}$ at $4{ }^{\circ} \mathrm{C}$. All of the subsequent steps were performed on ice. The resulting pellet was then resuspended in mitochondrial isolation buffer (215 mM mannitol, $75 \mathrm{mM}$ sucrose, 0.1\% BSA, 1 mM EGTA, 20 mM HEPES, pH 7.2) and homogenized on ice with a glass homogenizer. The mitochondria were then purified by differential centrifugation at $1300 \mathrm{~g}$ for 5 min to pellet unbroken cells and the nuclei. The supernatant fraction was then centrifuged at $13000 \mathrm{~g}$ for $10 \mathrm{~min}$ to pellet the mitochondria. The pellet was resuspended in EGTA-free isolation buffer. Briefly, complex I activity was assayed by monitoring the decrease of NADH at 340 $\mathrm{nm}$. Final concentration of mitochondrial protein was 30 $\mathrm{mg} / \mathrm{mL}$. Reaction was started by adding $200 \mathrm{mM}$ NADH and scanned at $340 \mathrm{~nm}$ for $3 \mathrm{~min}$. Rotenone $(3 \mathrm{mM})$ was added into the reaction system as blank control. Complex II was assayed with mitochondria (final concentration 30 $\mathrm{mg} / \mathrm{mL}$ ), and the reaction was started with $10 \mathrm{mM}$ succinate and scanned at $600 \mathrm{~nm}$ for $2 \mathrm{~min}$. Complex III 
activity was measured in a mixture containing $250 \mathrm{mM}$ sucrose, $1 \mathrm{mM}$ EDTA, $50 \mathrm{mM} \mathrm{K}$ phosphate, $\mathrm{pH}$ adjusted to 6.5 to reduce autooxidation of reduced coenzyme Q1 (CoQ1), $2 \mathrm{mM} \mathrm{KCN}, 50 \mathrm{mM}$ Cyto-c, 0.1\% BSA, and the reaction was initiated by $20 \mathrm{mg} / \mathrm{mL}$ mitochondria and 50 $\mathrm{mM}$ reduced $\mathrm{CoQ} 1$, recording the increase of absorption at $550 \mathrm{~nm}$ for $2 \mathrm{~min}$ [38].

\section{Western blot analysis}

To obtain cytosolic and mitochondrial fractions, the cells were incubated with buffer $(20 \mathrm{mM}$ Hepes, $1 \mathrm{mM}$ EDTA, $10 \mathrm{mM} \mathrm{KCl}, 1.5 \mathrm{mM} \mathrm{MgCl}$, $1 \mathrm{mM}$ EGTA, $1 \mathrm{mM}$ dithiothreitol, $250 \mathrm{mM}$ sucrose, aprotinin, leupeptin and pepstain $2 \mathrm{mg} / \mathrm{mL}$ each, $\mathrm{pH} 7.5$ ) on ice for $30 \mathrm{~min}$. After the cells were disrupted in a glass dounce homogenizer by optimized gentle strokes, homogenates were centrifuged at $1000 \mathrm{~g}$ for $10 \mathrm{~min}$ at $4{ }^{\circ} \mathrm{C}$ to remove nuclei. The supernatant were further centrifuged at $12,000 \mathrm{~g}$ at $4{ }^{\circ} \mathrm{C}$ for 30 min to separate the miochondria and cytosol fractions. To prepare whole cell lysates, the cells were harvested and incubated with lysis buffer by votex. After centrifugation at $13,000 \mathrm{~g}$ at $4{ }^{\circ} \mathrm{C}$ for $30 \mathrm{~min}$ to separate the cellular debris, the supernatant was collected and stored at -80 ${ }^{\circ} \mathrm{C}$ until use. The protein concentrations were determined using BCA protein assay kit according to the manufacture's instructions.

Cell lysates (10 mg protein per lane) were subjected to $10 \%$ SDS-PAGE, then transferred to nitrocellulose membranes and blocked with 5\% non-fat milk/Tris-buffered saline with Tween (TBST) for $1 \mathrm{~h}$ at room temperature. Membranes were incubated with primary antibodies directed against $\beta$-actin (1:10 000), p-JNK, Bax, cyto-C Bax, Bcl 2 and AIF in $5 \%$ milk/TBST at $4{ }^{\circ} \mathrm{C}$ overnight. After washing with TBST three times, membranes were incubated with horseradish peroxidase-conjugated secondary antibody for $1 \mathrm{~h}$ at room temperature. Western blots were developed using ECL (Roche Mannheim, Germany) and quantified by scanning densitometry [39]. Relative protein expressions determined by Western blotting were normalized to $\beta$-actin expression. Results were presented as percent control.

\section{Statistics}

All values are expressed as mean \pm S.E.M. Statistical significance was determined by using one-way ANOVA with Bonferroni's post hoc tests between the two groups. The criterion for significance was set at $\mathrm{P}<0.05$.

\section{Results}

\section{Characterization of OMs}

The $M w$ of OMs was $1678 \mathrm{Da}$ for OM1.5, $3317 \mathrm{Da}$ for OM3.0, 3910 Da for OM4.0, 5266 Da for OM5.0, respectively (Table 1). And the FT-IR spectrums of OMs are
Table 1 The relative weight-average molecular weight $(M w)$, total sugar content and uronic acid content of OMs

\begin{tabular}{lllll}
\hline Samples & $\boldsymbol{M}_{\mathbf{w}}(\mathrm{Da})$ & $\mathbf{D}$ & Total sugar (\%) & Uronic acid (\%) \\
\hline OM1.5 & 1678 & 1.02 & $93.27 \pm 1.39$ & $88.58 \pm 1.88$ \\
OM3.0 & 3317 & 1.21 & $93.47 \pm 0.80$ & $88.83 \pm 0.92$ \\
OM4.0 & 3910 & 1.34 & $94.21 \pm 1.64$ & $91.46 \pm 0.93$ \\
OM5.0 & 5266 & 1.40 & $95.17 \pm 2.46$ & $93.28 \pm 1.08$ \\
\hline
\end{tabular}

shown in Fig. 1a. The data revealed the bands at around $3398 \mathrm{~cm}^{-1}$ were assigned to symmetric stretching vibration of the hydroxyl group. The band at around 1729 $\mathrm{cm}^{-1}$ was attributed to $\mathrm{C}=\mathrm{O}$ stretching of carboxyl. The asymmetric and symmetric stretching of carboxylate vibrations appeared at $1610 \mathrm{~cm}^{-1}$ and $1414 \mathrm{~cm}^{-1}$. The band at around $1098 \mathrm{~cm}^{-1}$ (C-O-C stretching) and 1039 $\mathrm{cm}^{-1}$ (C-O stretching) were the characteristic absorption bands of polysaccharide structure. The band at around $934 \mathrm{~cm}^{-1}$ was the characteristic asymmetric stretching vibration of pyranose rings. The bands appeared at 816 $\mathrm{cm}^{-1}$ were mannopyranuronic acid. Therefore the products obtained from depolymeration of the PM remained mannuronate structure.

The structures of MOs were further characterized by NMR spectroscopy. To take OM3.0 as an example, the chemical shifts of anomeric protons were assigned according to ${ }^{1} \mathrm{H}-\mathrm{NMR}$ spectrum. As shown in Fig. 1b, the apparent single peak at $5.22 \mathrm{ppm}$ and double peak at 4.91-4.94 ppm corresponded to the reducing-end $\mathrm{H} 1$ and $\mathrm{H} 1 \beta$ signals respectively. The signal at $4.77 \mathrm{ppm}$ was observed for the middle ring $\mathrm{C} 1 \mathrm{H}$ signal. The peak at $4.65 \mathrm{ppm}$ was seen for the $\mathrm{C} 1$ proton of non-reducingend. The signals between $3.6 \mathrm{ppm}$ and $4.0 \mathrm{ppm}$ were assigned to $\mathrm{H} 2, \mathrm{H} 3, \mathrm{H} 4$ and $\mathrm{H} 5$ of the reducing end, middle residue and non-reducing end. The $600 \mathrm{MHz}$ ${ }^{13} \mathrm{C}$ NMR spectra of OM3.0 are given in Fig. 1c. Chemical shifts were unambiguously assigned. A single peak at 175.49-176.23 ppm was seen for the C6 of pyranose rings. The peak at around $94 \mathrm{ppm}$ corresponded to the $\mathrm{C} 1$ signals of the reducing end. Peaks at $101.51 \mathrm{ppm}$ and $100.05 \mathrm{ppm}$ were assigned to $\mathrm{C} 1$ of non-reducing end and the middle ring, respectively. The signal appeared at $77.75 \mathrm{ppm}$ was assigned to $\mathrm{C} 4 \mathrm{r}$ and $\mathrm{C} 4 \mathrm{~m}$. The signal appeared at $75.84 \mathrm{ppm}$ was seen for the $\mathrm{C} 4 \mathrm{n} / \mathrm{C} 5 \mathrm{r} \beta / \mathrm{C} 5 \mathrm{~m}$. The peak at $72.72 \mathrm{ppm}$ was assigned to the resonance of C5n. The signals appeared around 69-72 ppm were attributed to $\mathrm{C} 3$ and $\mathrm{C} 2$ of pyranose rings, respectively.

\section{Cell toxicities of OMs}

As shown in Fig. 2, treatment of RINm5F cells with different concentrations of OMs indicated as OM1.5, OM3.0, OM4.0, OM5.0, tended to increase the cell viability 


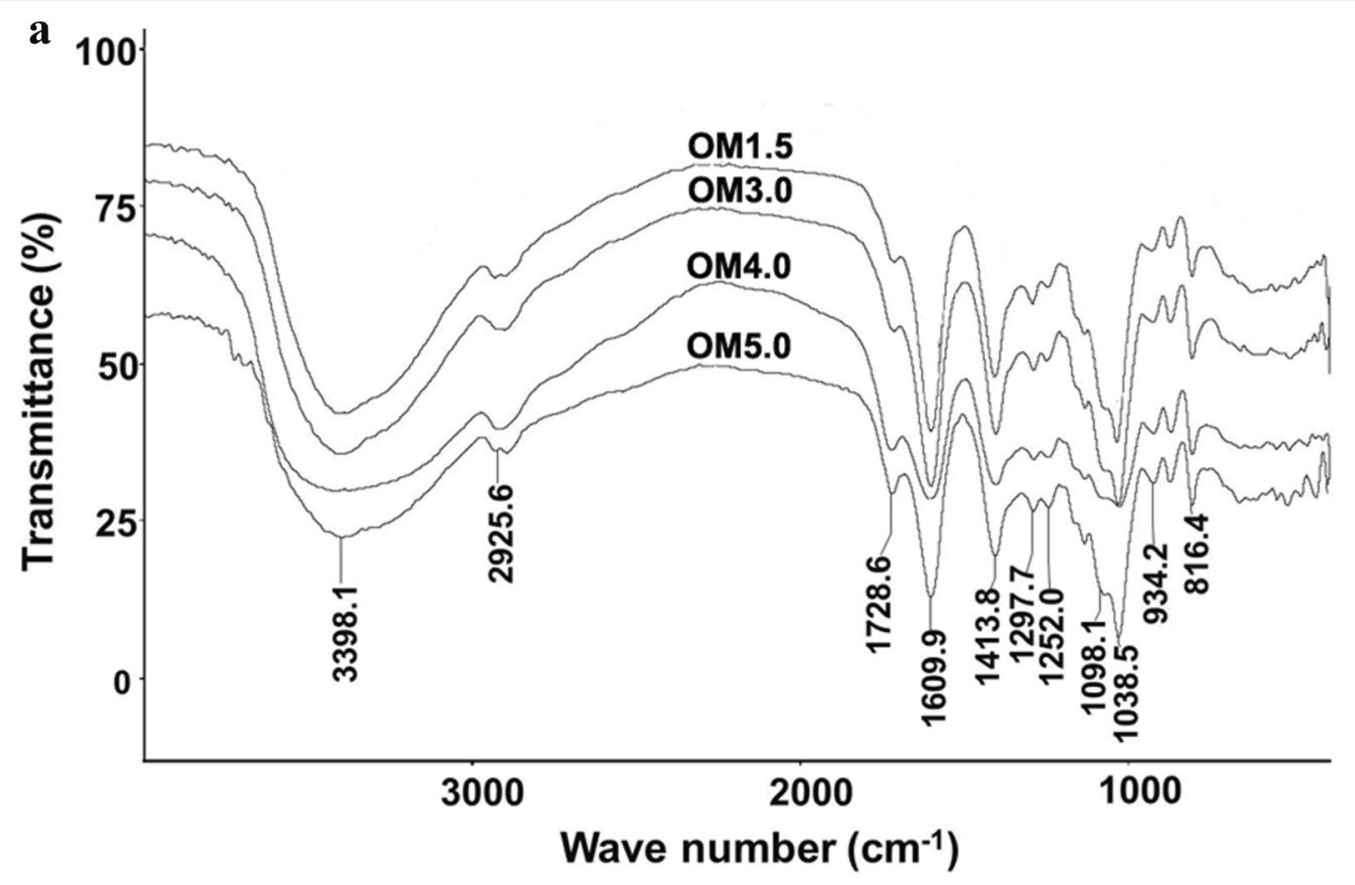

b

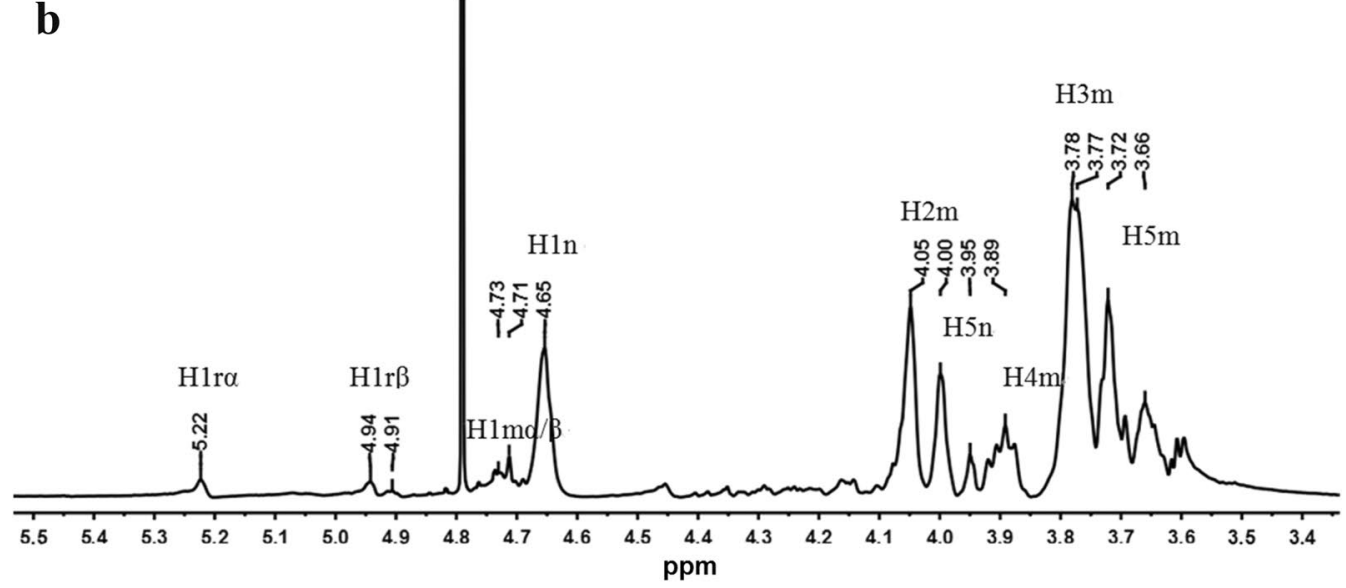

c

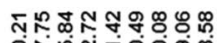

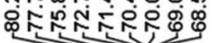

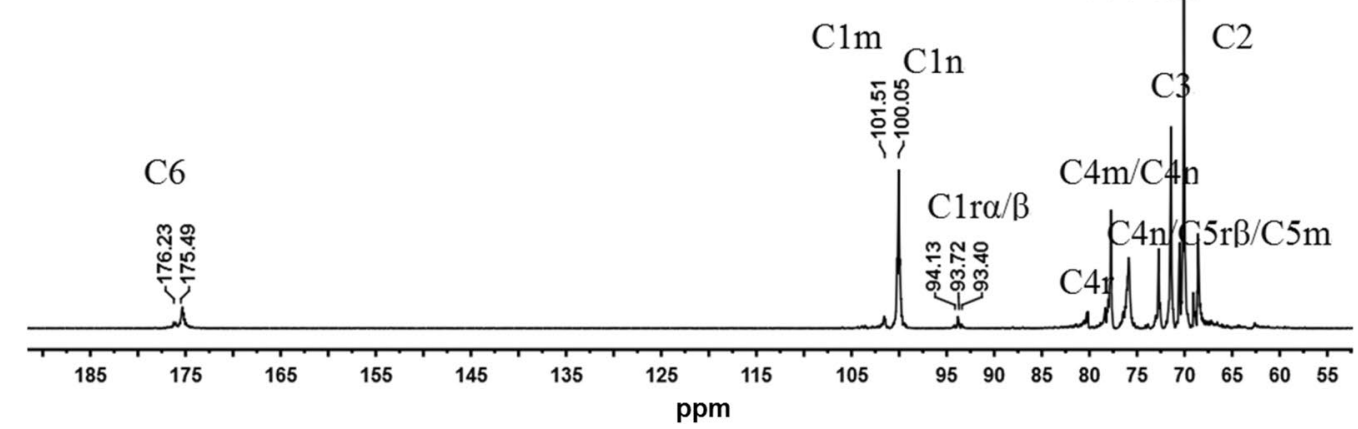

Fig. 1 The FTIR and 1D-NMR analysis. a FTIR spectrum of OMs. $\mathbf{b}^{1} \mathrm{H}-\mathrm{NMR}$ spectrum of OM3.0. $\mathbf{c}^{13} \mathrm{C}-\mathrm{NMR}$ spectrum of OM3.0 


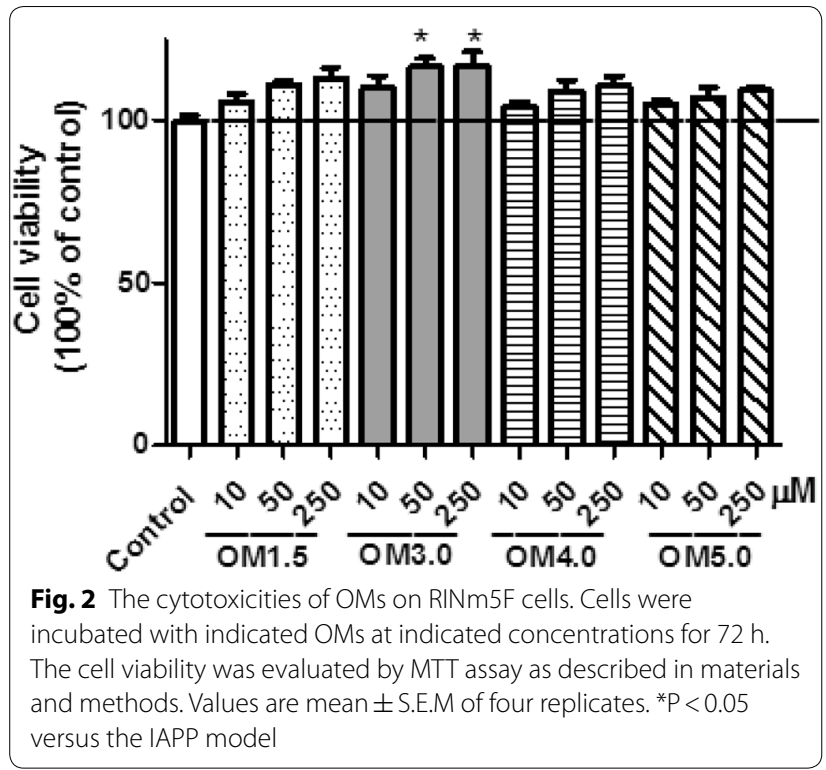

determined by MTT method, which demonstrated that OMs had no toxic effect on RINm5F cells within the ranged concentrations of $0-250 \mu \mathrm{M}$, and these results were in line with our previous report in $\mathrm{C} 2 \mathrm{C} 12$ skeletal muscle cells [30]. Meanwhile, the OM3.0 treatment could significantly increase the cell viability of RINm5F cells at levels of $50-250 \mu \mathrm{M}$. In addition, there was no obvious increase in the MTT assay of RINm5F cells induced with OMs at the concentration of $250 \mu \mathrm{M}$ as compared with $50 \mu \mathrm{M}$. So we choose the 10 and $50 \mu \mathrm{M}$ to continue our $\Delta \Psi$ m detection.

\section{Effect of OMs on mitochondrial membrane potential (MMP)}

As shown in Fig. 3a, pre-treatment of RINm5F cells with OMs at different concentrations as indicated could obviously inhibit the reductions of $\Delta \Psi \mathrm{m}$ in RINm5F cells induced by IAPP as determined by JC- 1 assay. And among the OMs with different molecular weights from $1.5 \mathrm{kDa}$ to $5.0 \mathrm{kDa}$, the OM3.0 with molecular weight of $3.0 \mathrm{kDa}$ tends to be the best one. Meanwhile, in the absence of IAPP additon, OMs had no effect on RINm5F cells within the ranged concentrations of $10-50 \mu \mathrm{M}$.

Then the ROS production was examined and the results were shown in Fig. 3b, IAPP treatment at $250 \mathrm{nM}$ for $24 \mathrm{~h}$ led to significantly increase in ROS production in RINm5F cells, and pre-treatment of the cells with the OMs could distinctly inhibit ROS production induced by IAPP.

Meanwhile, OMs also had no effect on RINm5F cells within the ranged concentrations of $10-50 \mu \mathrm{M}$. In addition, it is obviously that the optimal concentration of

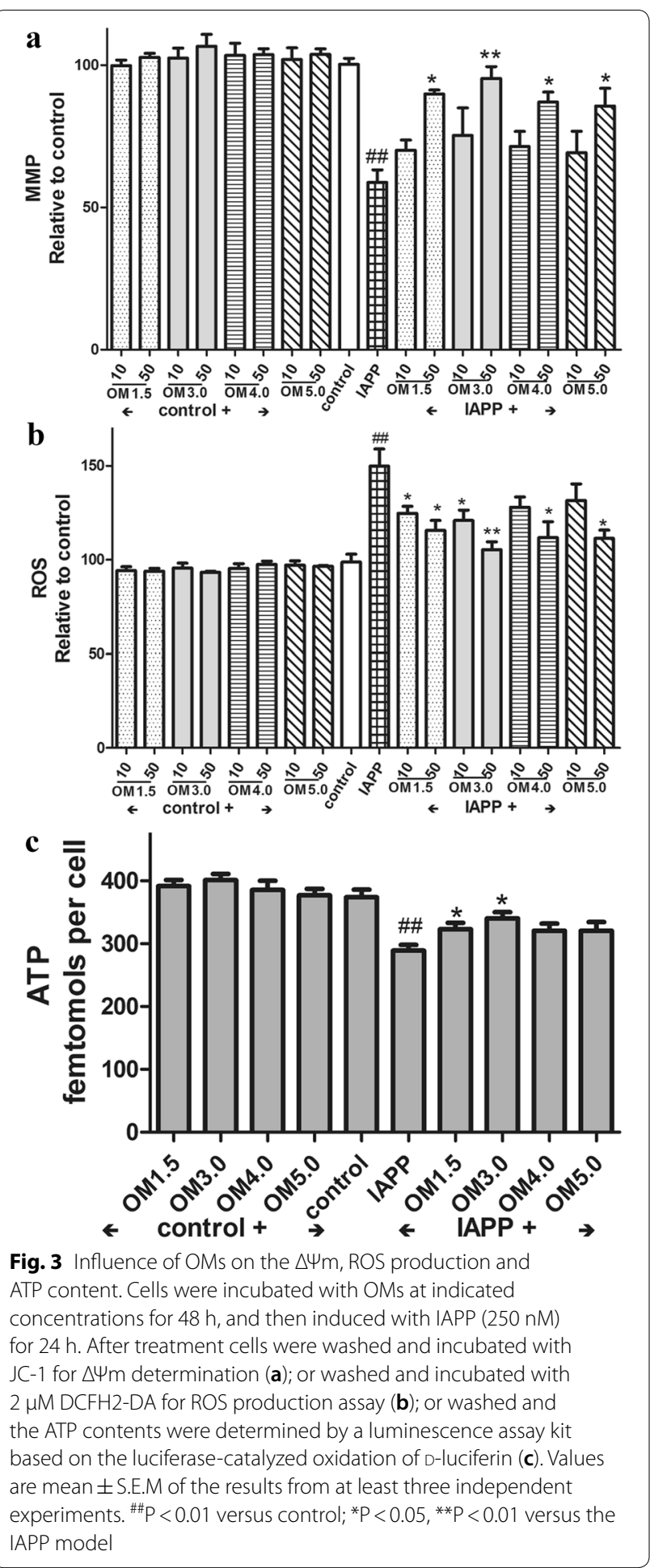

OMs to exert their protective effects on RINm5F cells induced by IAPP is $50 \mu \mathrm{M}$, which was in line with the results of JC-1 assay. And similarly, the OM3.0 was 
the best one to protect the RINm5F cells from damage induced by IAPP.

Based on the data shown in Fig. 3a, b, the effective concentration of OMs to protect RINm5F cells was optimized at $50 \mu \mathrm{M}$. Thus, the RINm5F cells were then treated with OMs at concentrations of $50 \mu \mathrm{M}$. Figure 3c showed that the ATP levels was significantly reduced by IAPP addition, and the OMs pre-treatment at $50 \mu \mathrm{M}$ could obviously prevent the islet beta cells from decrease in ATP content in RINm5F cells stimulated by IAPP. The OM3.0 as well tended to be the most effective one to protect RINm5F cells.

\section{Effect of OMs on mitochondrial functions}

We next measured if the OMs induced increase in $\Delta \Psi \mathrm{m}$ and ATP content were correlated with enhanced mitochondrial functions. Figure 4 indicated that the OMs pre-treatment at $50 \mu \mathrm{M}$ could significantly inhibit the decrease of oxygen consumption (Fig. 4a, b) in the RINm5F cells induced by IAPP treatment, which was associated with the up-regulation of mitochondrial complex I (Fig. 4c), complex II (Fig. 4d) and complex III (Fig. 4e) activities by OMs pre-incubation in the beta cells followed by IAPP induction. All these results presented in Figs. 3, 4 showed that the OMs, especially the OM3.0 could distinctly enhance mitochondrial functions, which were associated not only with increased $\Delta \Psi \mathrm{m}$, ATP levels, oxygen consumption and complex I-III activities, but also with decreased ROS production.

\section{Effect of OM3.0 on key-protein expressions of JNK signaling pathway}

Figures 2, 3 and 4 demonstrated that the optimal effect of stimulation was found to be at $50 \mu \mathrm{M}$, and OM3.0 was the most effective compound among the four kinds of oligosaccharides with different molecular weight. Thus, the RINm5F cells were then treated with OM3.0 at concentrations of $50 \mu \mathrm{M}$ to continue our experiments. It was reported that JNK signaling pathway play important roles in the damage and dysfunction of islet beta cells [40]. We performed the western blotting assays for determination of JNK activation and expression of cell apoptotic regulating proteins and factors. As shown in Fig. 5 , the p-JNK level was significantly up-regulated by IAPP induction for $24 \mathrm{~h}$ at $250 \mathrm{nM}$ (Fig. 5a), the protein expressions in $\mathrm{Bcl}-2$ and $\mathrm{Bax}$ were also obviously changed by IAPP induction (Fig. 5b), which were correlated with the increased cytosolic Cyto-c content and AIF levels, and the elevated cytosolic Cyto-c and AIF release were accompanied by the decreased mitochondrial Cyto-c and AIF levels (Fig. 5c). After IAPP treatment of cells, it promotes the release of cytochrome $\mathrm{C}$ from mitochondria to the cytoplasm, which is also a sign of apoptosis. It is obvious that the OM3.0 pre-treatment could distinctly prevent the RINm5F cells from the JNK activation and apoptosis induced by IAPP addition.

\section{JNK activation was required for OM3.0 mediated effects}

To test if the increased mitochondrial function and reduced apoptosis were the results of the inhibited JNK pathway by the OM3.0 treatment, we decided to use the anisomycin to stimulate JNK activation to understand the relationship between them. As shown in Fig. 6a, OM3.0 dramatically inhibited the activation of JNK as determined by western blotting for $\mathrm{p}$-JNK expression, which were in agreement with Fig. 5a. But the inhibitory effect of OM3.0 on JNK activation was abrogated by anisomycin treatment, a specific JNK activator. Meanwhile, the increase of mitochondrial complex III activities and cellular ATP content stimulated by OM3.0 were both significantly reversed by anisomycin treatment (Fig. 6b, c). All these results demonstrated that the OM could prevent mitochondrial dysfunction induced by IAPP in RINm5F islet cells through JNK dependent signaling pathway.

\section{Disscussion}

A critical feature of diabetic pathogenesis is the presence of amyloid, that are associated with the death of insulin secreting beta cells. These amyloid deposits are composed primarily of protein fibers formed from IAPP (also known as amylin). IAPP is a 37 residue, natively unstructured peptide hormone that is co-packaged with insulin in the secretory granules of the beta cells $[4,6]$. In the present study, we demonstrated for the first time that mitochondrial dysfunction induced by hIAPP was dependent on the JNK signaling pathway in pancreatic beta cells. Our results showed that disruption of mitochondrial function in hIAPP induced RINm5F cell, as evidence by loss of MMP, suppressed mitochondrial complex activities, ATP depletion, decreased respiratory consumption, elevated apoptotic protein expression and Cyto-c release, was mediated by the JNK activation. Interestingly, these hIAPP-induced changes were significantly attenuated by OMs treatments, which were partially due to its ability to prevent mitochondrial dysfunction through a JNK mediated signaling pathway.

Recent years, lot of poly-/oligosaccharides have been investigated and showed anti-diabetic activities, for example, hypoglycemic activities have been revealed for chito-oligosaccharides, and oligosaccharides from two kinds of fungi [41-44]. But no information about the beneficial effect of OMs on the hIAPP-induced pancreatic beta cells. Due to the commercially wide use of OMs, we obtained several kinds of OMs with different molecular mass by microwave degradation, and compared their protective effects on the MMP loss induced by hIAPP in 


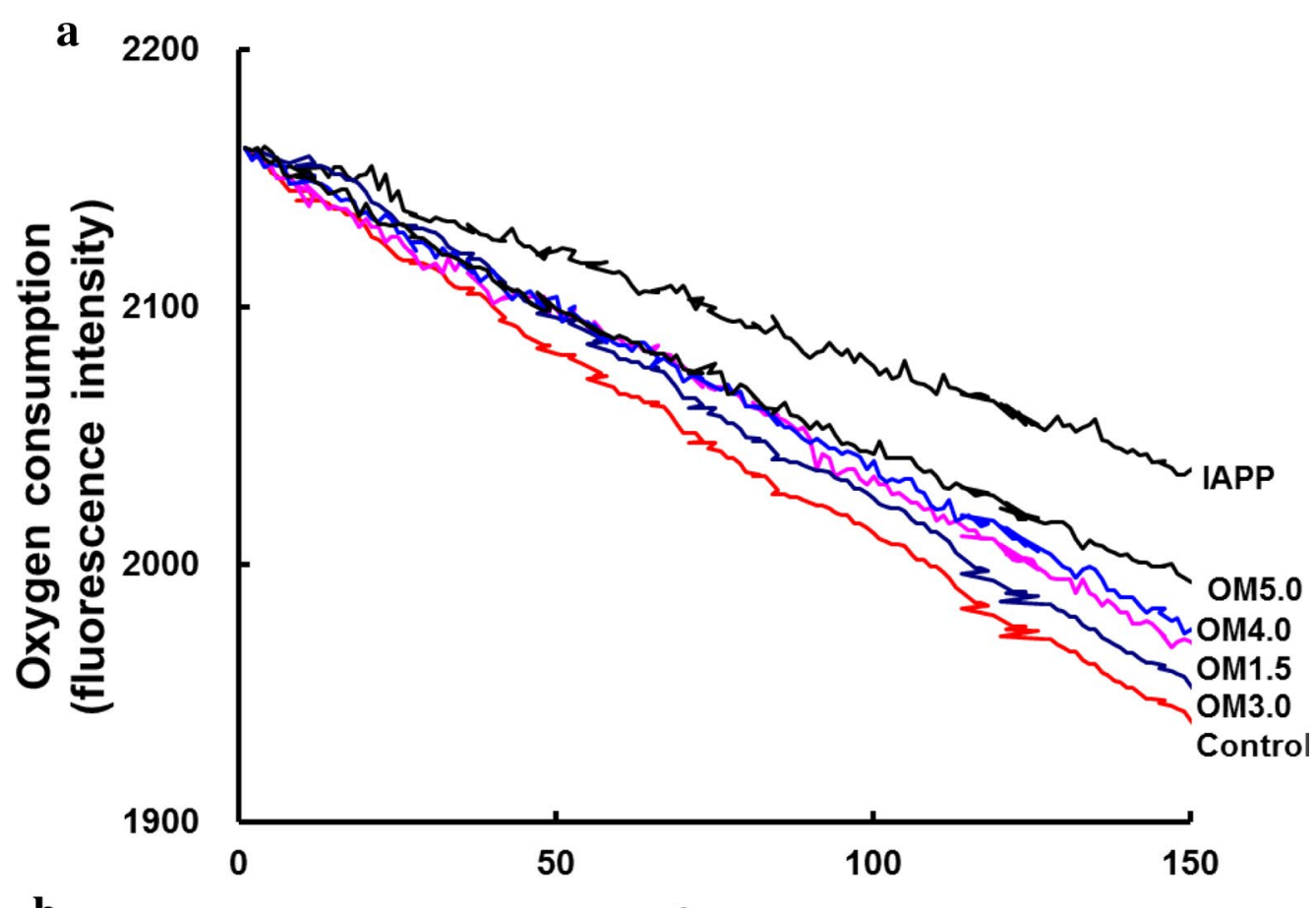

b
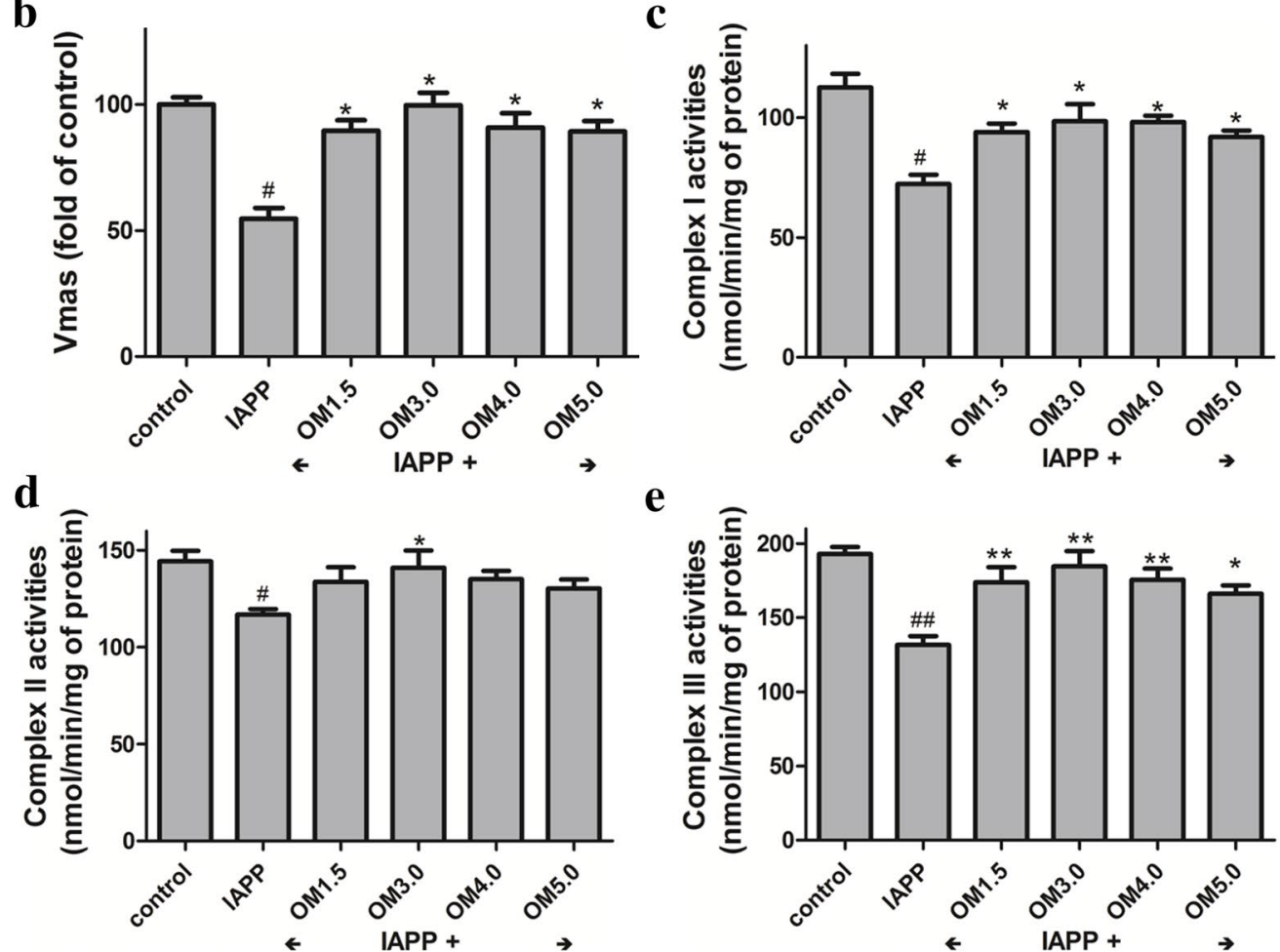

e

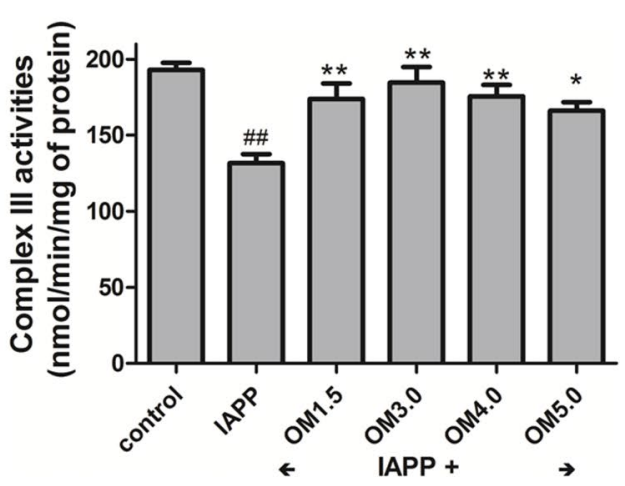

Fig. 4 OMs inhibited IAPP induced mitochondrial dysfunction in RINm5F cells. The Islet $\beta$ cells were seeded in 6 -well plates and treated with OMs at $50 \mu \mathrm{M}$ for $48 \mathrm{~h}$, and then induced with IAPP $(250 \mathrm{nM})$ for $24 \mathrm{~h}$. After treatment, cells were presented for oxygen consumption in that equal volumes of cells were separated into aliquots in wells of a 96-well BD Oxygen Biosensor plate. Fluorescence in each well was recorded over time. a Representative oxygen consumption curves. $\mathbf{b}$ Quantitative changes in the respiratory rate of the islet $\beta$ cells calculated by determining the kinetic measurements. Or the mitochondrial of RINm5F cells were isolated for detection of complex activities. c Mitochondrial complex I activity assay. $\mathbf{d}$ Mitochondrial complex II activity assay. e Mitochondrial complex III activity assay. Values are mean \pm S.E.M of the results from at least three independent experiments. ${ }^{\#} \mathrm{P}<0.01$ versus control, ${ }^{*} \mathrm{P}<0.05$ versus the IAPP model 


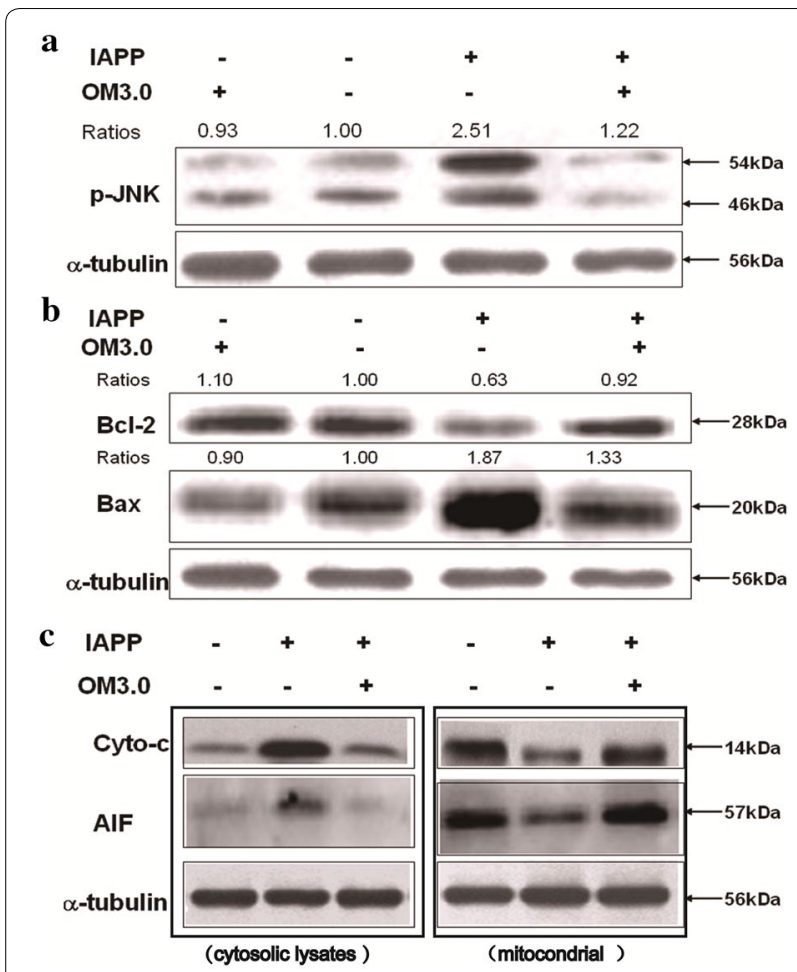

Fig. 5 OM3.0 suppressed JNK activation and cell apoptosis in IAPP induced islet $\beta$ cells. RINm5F cells in 6-well plates were treated with OMs at $50 \mu \mathrm{M}$ for $48 \mathrm{~h}$, and then induced with IAPP ( $250 \mathrm{nM}$ ) for $24 \mathrm{~h}$. a Inhibition of JNK activation by OM3.0 treatment. Cell lysates were subjected to western blot analysis of phosporylated JNK. a-tubulin was used as an internal control. b Effect of OM3.0 on protein expression of $\mathrm{BCl}-2$ and Bax. Cell lysates were subjected to westrern blot analysis of $\mathrm{BCl}-2$ and Bax, a-tubulin was used as an internal control. c OM3.0 prevented IAPP induced changes of Cyto-c and AIF release from mitochondria into cytosol. The treated cells were separated into cytosolic and mitochondrial fractions. Cell lysates were subjected to western blot analysis. Changes in levels of protein expression (shown as ratios) were calculated based on levels in corresponding untreated cells, which were set at unity. Data represent similar results from three independent experiments

RINm5F cells. In the present work, several water-soluble OMs were prepared by microwave-irradiation method. The molecular weights of OMs were about $1.5-5.0 \mathrm{kDa}$, as determined by HPGPC-MALLS. And the results showed that OMs, especially for the molecular weight of $3.0 \mathrm{kDa}$, could effectively inhibit the MMP loss in hIAPPtreated RINm5F cells. In our previous study, we also found that the OM-derived chromium (III) complexes with the molecular weight of around $3.0 \mathrm{kDa}$ significantly stimulated insulin sensitivity in $\mathrm{C} 2 \mathrm{C} 12$ skeletal muscles [30]. These data demonstrated an optimized concentration of $\mathrm{OM}$ around $3.0 \mathrm{kDa}$ to exert its bioactivity on skeletal or pancreatic islet beta cells, which could share some insight for its potential in industrial applications.
The mitochondrion of pancreatic beta cell is a key organelle for control of insulin secretion. Several published studies revealed that beta cell apoptosis due to mitochondrial dysfunction was especially apparent in pancreatic beta cells $[8,9]$. The mitochondrial respiratory chain is a major source of ROS whose overproduction of ROS will further impair mitochondrial electron transport to cause more ROS release. ROS has been highlighted as initiators for hIAPP-induced cytotoxicity in pancreatic beta cells. Previous findings suggested that over-production of ROS was involved in hIAPP-induced beta cell toxicity [1, 13, 45]. Moreover, ROS are known to affect MMP, and the loss of MMP induces release of mitochondrial apoptogenic factors, such as Cyto-c and AIF [10, 11]. Once in the cytol, Cyto-c binds to adaptor molecule apoptotic protease activating factor I (Apaf-1) in the presence of ATP and activates caspase- 9 , which in turn activates caspase- 3 and cleaves downstream PARP, and eventually leads to cell apoptosis [46]. In contrast to Cyto-c, AIF mediated the apoptotic cell death trough a caspase-independent pathway [47]. In the present study, we found that hIAPP treatment induced intracellular ROS generation in RINm5F cells accompanied with damages in mitochondrial function, including loss of MMP, depletion of ATP, release of apoptogenic factors such as Cyto-c and AIF, increased expression of Bax, and decreased expression Bcl-2, which was attenuated by co-treatment with OMs. Meanwhile, the JNK activation and downstream targets were also down-regulated by OMs treatments in pancreatic beta cells. These results suggest that $\mathrm{OM}$ is capable of scavenging free radicals and protects RINm5F cells against hIAPP-induced mitochondrial damage, which was associated with the activation of JNK signaling pathway.

JNK signaling has an established role in the regulation of cell apoptosis through the activation of transcription factors and phosphorylation of apoptosis-related proteins $[40,48,49]$. The JNK signaling pathway has been reported to affect members of the Bcl-2 family. For example, JNK not only can inactivate anti-apoptotic Bcl-2 proteins but also can activate the mitochondrial translocation of Bax [50]. But conversely, there is growing evidence that JNK signaling can induce pro-survival pathways in certain cell types, including neurons, $\mathrm{T}$ cells and $\mathrm{B}$ lymphocytes $[51,52]$. Thus, the role of JNK is complex in the mediation of distinct cellular response depending on cell contents. In addition, different concentrations of hIAPP could result in different cellular responses, for example, the activation of NADPH-oxidase induced by hIAPP at $60 \mathrm{nM}$ was converse to the concentration at $500 \mathrm{nM}$ [53]. And recent researches were focused on the molecular or signal changes induced by hIAPP at $\mu \mathrm{M}$ levels $[1$, $6,7,16,40,54]$. And in RINm5F cells, activation of JNK 
$\mathbf{a}$
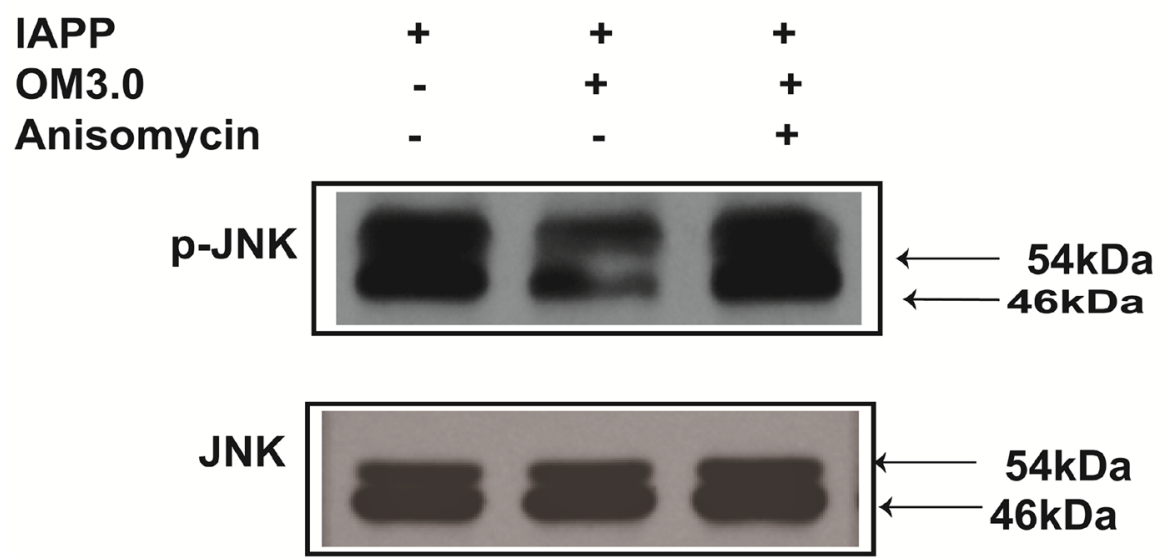

b

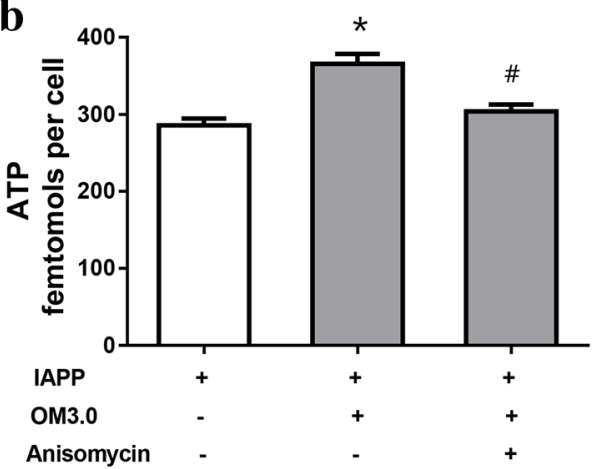

c

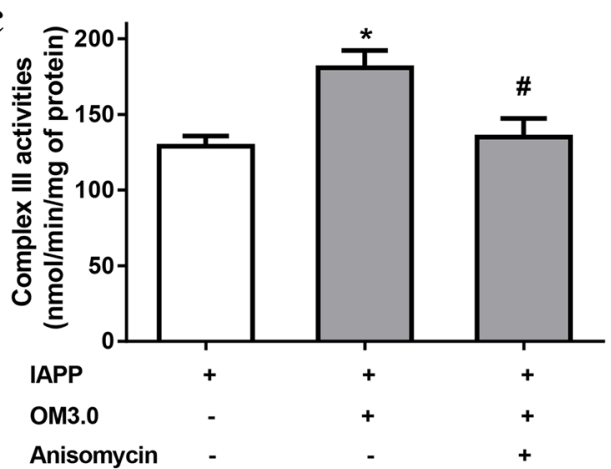

Fig. 6 Requirement of JNK activation in OM3.0 mediated changes in IAPP induced RINm5F cells. Cells were pretreated with OM3.0 and IAPP for 16 $\mathrm{h}$ and then with or without anisomycin as described. Protein isolates were subjected to $\mathbf{a}$ western blot analysis of JNK activation, $\mathbf{b}$ determination of complex III activity, and $\mathbf{c}$ assay of ATP content. Change in level of JNK phosphorylation (shown as ratio) was calculated based on level in corresponding untreated cells, which were set at unity. Values are mean \pm S.E.M of the results from at least three independent experiments. ${ }^{\#} \mathrm{P}<0.01$ versus control, ${ }^{*} \mathrm{P}<0.05$ versus the IAPP model, ${ }^{\nabla} \mathrm{P}<0.05$ versus the anisomycin treatment

was associated with hIAPP-induced cell damage $[15,54]$. In the present study, we firstly found that hIAPP at 250 nM could effectively stimulate the activation of JNK in RINm5F cells. In support of the pro-apoptosis functions of JNK in the presence of hIAPP, our results also demonstrated that the protective effects of OM on beta cells were partially mediated by suppressing the activation of JNK pathway.

The signal interactions of JNK with mitochondria were complicated as reported [18-22], in the present study, we demonstrated for the first time that the mitochondrial dysfunction induced by hIAPP was dependent on the activation of JNK. Meanwhile, the stimulation of JNK by specific activators also obviously abrogated the beneficial effect of OM on the hIAPP-induced mitochondrial damage in RINm5F cells, indicating the prevention of mitochondrial damage in IAPP-treated RINm5F islet cells by OM treatment was through a JNK dependent signaling pathway.

\section{Conclusions}

In this study, our results provide strong evidence that hIAPP-induced mitochondrial dysfunction in RINm5F islet beta cells through was through activation of JNK signaling pathway. Moreover, treatment with OM effectively attenuated hIAPP-induced loss of MMP, ATP depletion, reduced mitochondrial complex activities, decreased $\mathrm{Bcl}-2$, increased Bax levels protein and release of Cyto-c, these effects were in part mediated by the activation of JNK. The present work enhances our understanding of the molecular mechanisms of hIAPP-induced pancreatic mitochondrial dysfunction and indicates the potential therapeutic role of $\mathrm{OM}$ in type 2 diabetes by preventing hIAPP-induced loss of pancreatic beta cells.

\section{Abbreviations}

MMP: Mitochondrial membrane potential; JC-1: J-Aggregate forming lipophilic cation 55',6,6'-tetrachloro-1,1',3,3' tetraethylbenzimidazolcarbocyanine iodide; BSA: Bovine serum albumin; ddH2O: Double-distilled water; OM: 
Oligomannuronates; IAPP: Human Islet amyloid polypeptide; JNK: c-Jun $\mathrm{N}$-terminal protein kinase; DCFH2-DA: 2,7'-Dichlorofluorescin diacetate.

\section{Acknowledgements}

This research was supported by National Science Foundation of China (81402982, 81973231), and Qingdao Independent Innovation Project (13-7-1-zdzx1-hy).

\section{Authors' contributions}

$X \mathrm{~L}, \mathrm{QL}$ conceived the manuscript and performed the experiments; $X \mathrm{C}, Z \mathrm{~L}, \mathrm{XZ}$, SZ and GY contributed to the resources; $X Z$ and $J H$ designed and directed the project. All authors read and approved the final manuscript.

\section{Funding}

National Science Foundation of China (81402982, 81973231), and Qingdao

Independent Innovation Project (13-7-1-zdzx1-hy)

\section{Availability of data and materials}

The datasets used during the present study are available from the corresponding author upon reasonable request.

\section{Ethics approval and consent to participate}

This article does not contain any animal experiments.

\section{Consent for publication}

Not relevant to this manuscript.

\section{Competing interests}

The authors declare that they have no competing interests.

\begin{abstract}
Author details
${ }^{1}$ Laboratory for Marine Drugs and Bioproducts, Qingdao National Laboratory for Marine Science and Technology, Qingdao 266237, China. ${ }^{2}$ School of Medicine and Pharmacy, Ocean University of China, Qingdao 266003, China. ${ }^{3}$ The Affiliated Central Hospital of Qindao University, The Qindao University, Qindao 266001, China. ${ }^{4}$ LanZhou University of Technology, School of Life Science and Engineering, Lanzhou 730050, China.
\end{abstract}

Received: 10 January 2020 Accepted: 13 March 2020

Published online: 24 March 2020

\section{References}

1. Zraika S, Hull RL, Udayasankar J, Aston-Mourney K, Subramanian SL, Kisilevsky R, Szarek WA, Kahn SE. Oxidative stress is induced by islet amyloid formation and time-dependently mediates amyloid-induced beta cell apoptosis. Diabetologia. 2009;52:626-35.

2. Westermark P, Wernstedt C, Wilander E, Hayden DW, O'Brien TD, Johnson $\mathrm{KH}$. Amyloid fibrils in human insulinoma and islets of Langerhans of the diabetic cat are derived from a neuropeptide-like protein also present in normal islet cells. Proc Natl Acad Sci USA. 1987;84:3881-5.

3. Cao P, Marek P, Noor H, Patsalo V, Tu LH, Wang H, Abedini A, Raleigh DP. Islet amyloid: from fundamental biophysics to mechanisms of cytotoxicity. FEBS Lett. 2013;587:1106-18.

4. Haataja L, Gurlo T, Huang CJ, Butler PC. Islet amyloid in type 2 diabetes, and the toxic oligomer hypothesis. Endocr Rev. 2008;29:303-16.

5. Hoppener JWM, Lips CJM. Role of islet amyloid in type 2 diabetes mellitus. Int J Biochem Cell Biol. 2006:38:726-36.

6. Lin CY, Gurlo T, Kayed R, Butler AE, Haataja L, Glabe CG, Butler PC. ToxiC human islet amyloid polypeptide (h-IAPP) oligomers are intracellular, and vaccination to induce anti-toxic oligomer antibodies does not prevent h-IAPP-induced beta-cell apoptosis in h-IAPP transgenic mice. Diabetes. 2007:56:1324-32.

7. Li X, Chen T, Wong Y, Xu G, Fan R, Zhao H, Chan JCN. Involvement of mitochondrial dysfunction in human islet amyloid polypeptide-induced apoptosis in INS-1E pancreatic beta cells: an effect attenuated by phycocyanin. Int J Biochem Cell Biol. 2011;43:525-34.

8. Trifunovic A, Larsson NG. Mitochondrial dysfunction as a cause of ageing. J Intern Med. 2008;263:167-78.
9. Butler AE, Janson J, Bonner-Weir S, Ritzel R, Rizza RA, Butler PC. Beta-cell deficit and increased beta-cell apoptosis in humans with type 2 diabetes. Diabetes. 2003;52:102-10.

10. Gupta S, Kass GEN, Szegezdi E, Joseph B. The mitochondrial death pathway: a promising therapeutic target in diseases. J Cell Mol Med. 2009;13:1004-33.

11. Jourdain A, Martinou JC. Mitochondrial outer-membrane permeabilization and remodelling in apoptosis. Int J Biochem Cell Biol. 2009:41:1884-9.

12. Maedler K, Schulthess FT, Bielman C, Berney T, Bonny C, Prentki M, Donath MY, Roduit R. Glucose and leptin induce apoptosis in human beta-cells and impair glucose-stimulated insulin secretion through activation of c-Jun N-terminal kinases. FASEB J. 2008;22:1905-13.

13. Kaneto H, Matsuoka TA, Nakatani Y, Kawamori D, Miyatsuka T, Matsuhisa M, Yamasaki Y. Oxidative stress, ER stress, and the JNK pathway in type 2 diabetes. J Mol Med. 2005:83:429-39.

14. Cunha DA, Hekerman P, Ladriere L, Bazarra-Castro A, Ortis F, Wakeham MC, Moore F, Rasschaert J, Cardozo AK, Bellomo E, Overbergh L, Mathieu C, Lupi R, Hai T, Herchuelz A, Marchetti P, Rutter GA, Eizirik DL, Cnop M. Initiation and execution of lipotoxic ER stress in pancreatic beta-cells. J Cell Sci. 2008;121:2308-18.

15. Zhang S, Liu J, Dragunow M, Cooper GJ. Fibrillogenic amylin evokes islet beta-cell apoptosis through linked activation of a caspase cascade and JNK1. J Biol Chem. 2003;278:52810-9.

16. Li X, Xu G, Chen T, Wong Y, Zhao H, Fan R, Gu X, Tong PCY, Chan JCN. Phycocyanin protects INS-1E pancreatic beta cells against human islet amyloid polypeptide-induced apoptosis through attenuating oxidative stress and modulating JNK and p38 mitogen-activated protein kinase pathways. Int J Biochem Cell Biol. 2009;1:1526-35.

17. Zhang S, Liu J, MacGibbon G, Dragunow M, Cooper GJ. Increased expression and activation of c-Jun contributes to human amylin-induced apoptosis in pancreatic islet beta-cells. J Mol Biol. 2002;324:271-85.

18. Dhanasekaran DN, Reddy EP. JNK signaling in apoptosis. Oncogene. 2008;27:6245-51.

19. Chambers JW, Pachori A, Howard S, lqbal S, Lograsso PV. Inhibition of JNK mitochondrial localization and signaling is protective against ischemia/ reperfusion injury in rats. J Biol Chem. 2013;288:4000-11.

20. Dougherty CJ, Kubasiak LA, Frazier DP, Li H, Xiong WC, Bishopric NH, Webster KA. Mitochondrial signals initiate the activation of c-Jun N-terminal kinase (JNK)by hypoxia-reoxygenation. FASEB J. 2004;18:1060-70.

21. Hanawa N, Shinohara M, Saberi B, Gaarde WA, Han D, Kaplowitz N. Role of JNK translocation to mitochondria leading to inhibition of mitochondria bioenergetics in acetaminophen-induced liver injury. J Biol Chem. 2008;283:13565-77.

22. Wang L, Tu Y, Huang C, Ho C. JNK signaling is the shared pathway linking neuroinflammation, blood-brain barrier disruption, and oligodendroglial apoptosis in the white matter injury of the immature brain. J Neuroinflamm. 2012;9:175.

23. Li L, Jiang X, Guan H, Wang P. Preparation, purification and characterization of alginate oligosaccharides degraded by alginate lyase from Pseudomonas sp. HZJ 216. Carbohydrat Res. 2011;346:794-800.

24. Choi D, Piao YL, Shin WS, Cho H. Production of oligosaccharide from alginate using Pseudoalteromonas agarovorans. Appl Biochem Biotechnol. 2009;159:438-52.

25. Natsume M, Kamo Y, Hirayama M, Adachi T. Isolation and characterization of alginate-derived oligosaccharides with root growth-promoting activities. Carbohyd Res. 1994;258:187-97.

26. Hu J, Geng M, Li J, Xin X, Wang J, Tang M, Zhang J, Zhang X, Ding J. Acidic oligosaccharide sugar chain, a marine-derived acidic oligosaccharide, inhibits the cytotoxicity and aggregation of amyloid beta protein. J Pharmacol Sci. 2004;95:248-55.

27. Ma J, Xin X, Meng L, Tong L, Lin L, Geng M, Ding J. The marine-derived oligosaccharide sulfate (MdOS), a novel multiple tyrosine kinase inhibitor, combats tumor angiogenesis both in vitro and in vivo. PLOS ONE. 2008;3:e3774.

28. Wang XJ, Chen XH, Yang XY, Geng MY, Wang LM. Acidic oligosaccharide sugar chain, a marine-derived oligosaccharide, activates human glial cell line-derived neurotrophic factor signaling. Neurosci Lett. 2007;417:176-80

29. Wang S, Li J, Xia W, Geng M. A marine-derived acidic oligosaccharide sugar chain specifically inhibits neuronal cell injury mediated 
by beta-amyloid-induced astrocyte activation in vitro. Neurol Res. 2007;29:96-102

30. Hao C, Hao J, Wang W, Han Z, Li G, Zhang L, Zhao X, Yu G. Insulin sensitizing effects of oligomannuronate-chromium (III) complexes in C2C12 skeletal muscle cells. PLoS ONE. 2011;6:e24598.

31. Hu T, Li C, Zhao X, Li G, Yu G, Guan H. Preparation and characterization of guluronic acid oligosaccharides degraded by a rapid microwave irradiation method. Carbohyd Res. 2013;373:53-8.

32. Dubois M, Gilles K, Hamilton JK, Rebers PA, Smith F. A colorimetric methodfor the determination of sugars. Nature. 1951;168:167.

33. Bitter T, Muir HM. A modified uronic acid carbazole reaction. Anal Biochem. 1962;4:330-4.

34. Tirosh O, Sen CK, Roy S, Packer L. Cellular and mitochondrial changes in glutamate-induced HT4 neuronal cell death. Neuroscience. 2000;97:531-41.

35. Cathcart R, Schwiers E, Ames BN. Detection of picomole levels of hydroperoxides using a fluorescent dichlorofluorescein assay. Anal Biochem. 1983;134:111.

36. Patane G, Anello M, Piro S, Vigneri R, Purrello F, Rabuazzo AM. Role of ATP production and uncoupling protein-2 in the insulin secretory defect induced by chronic exposure to high glucose or free fatty acids and effects of peroxisome proliferator-activated receptor-gamma inhibition. Diabetes. 2002;51:2749-56.

37. Wilson-Fritch L, Nicoloro S, Chouinard M, Lazar MA, Chui PC, Leszyk J, Straubhaar J, Czech MP, Corvera S. Mitochondrial remodeling in adipose tissue associated with obesity and treatment with rosiglitazone. J Clin Invest. 2004;114:1281-9.

38. Sun L, Luo C, Long J, Wei D, Liu J. Acrolein is a mitochondrial toxin: effects on respiratory function and enzyme activities in isolated rat liver mitochondria. Mitochondrion. 2006;6:136-42.

39. Boudina S, Sena S, O'Neill BT, Tathireddy P, Young ME, Abel ED. Reduced mitochondrial oxidative capacity and increased mitochondrial uncoupling impair myocardial energetics in obesity. Circulation. 2005;112:2686-95.

40. Subramanian SL, Hull RL, Zraika S, Aston-Mourney K, Udayasankar J, Kahn SE. cJUN N-terminal kinase (JNK) activation mediates islet amyloidinduced beta cell apoptosis in cultured human islet amyloid polypeptide transgenic mouse islets. Diabetologia. 2012;55:166-74.

41. Zhang R, Zhou J, Jia Z, Zhang Y, Gu G. Hypoglycemic effect of Rehmannia glutinosa oligosaccharide in hyperglycemic and alloxan-induced diabetic rats and its mechanism. J Ethnopharmacol. 2004;90:39-43.

42. Liu B, Liu WS, Han BQ, Sun YY. Antidiabetic effects of chitooligosaccharides on pancreatic islet cells in streptozotocin-induced diabetic rats. World J Gastroenterol. 2007;13:725-31.
43. Lu XJ, Chen XM, Fu DX, Cong W, Ouyang F. Effect of Amorphophallus konjac oligosaccharides on STZ-induced diabetes model of isolated islets. Life Sci. 2002;72:711-9.

44. Wang $X$, Zheng $Y$, Fang J. Recent advances in the study on poly- and oligo-saccharides with hypoglycemic activity. Acta pharmaceutica Sinica. 2004;39:1028-33.

45. Konarkowska B, Aitken JF, Kistler J, Zhang S, Cooper GJ. The aggregation potential of human amylin determines its cytotoxicity towards islet betacells. FEBS J. 2006;273:3614-24.

46. Kroemer G, Reed JC. Mitochondrial control of cell death. Nat Med. 2000:6:513-9.

47. Krantic S, Mechawar N, Reix S, Quirion R. Apoptosis-inducing factor: a matter of neuron life and death. Prog Neurobiol. 2007;81:179-96.

48. Abdelli S, Abderrahmani A, Hering BJ, Beckmann JS, Bonny C. The c-Jun $\mathrm{N}$-terminal kinase JNK participates in cytokine- and isolation stressinduced rat pancreatic islet apoptosis. Diabetologia. 2007:50:1660-9.

49. Liu G, An Z. Protective effect of rosiglitazone sodium on islet beta-cell of STZ induced diabetic rats through JNK pathway. J Sichuan Univ Med Sci Ed. 2009;40:430-4.

50. Lee H, Wang C, Kuo H, Chou F, Jean L, Tseng T. Induction apoptosis of luteolin in human hepatoma HepG2 cells involving mitochondria translocation of Bax/Bak and activation of JNK. Toxicol Appl Pharmacol. 2005;203:124-31.

51. Liu J, Lin A. Role of JNK activation in apoptosis: a double-edged sword. Cell Res. 2005;15:36-42.

52. Xu L, Yu J, Zhai D, Zhang D, Shen W, Bai L, Cai Z, Yu C. Role of JNK activation and mitochondrial Bax translocation in allicin-induced apoptosis in human ovarian cancer SKOV3 cells. Evid Based Complement Altern Med. 2014;2014:378684.

53. Borchi E, Bargelli V, Guidotti V, Berti A, Stefani M, Nediani C, Rigacci S. Mild exposure of RIN-5F $\beta$-cells to human islet amyloid polypeptide aggregates upregulates antioxidant enzymes via NADPH oxidase-RAGE: an hormetic stimulus. Redox Biology. 2014;2:114-22.

54. Rumora L, Hadzija M, Barisic K, Maysinger D, Grubiic TZ. Amylin-induced cytotoxicity is associated with activation of caspase- 3 and MAP kinases. Biol Chem. 2002;383:1751-8.

\section{Publisher's Note}

Springer Nature remains neutral with regard to jurisdictional claims in published maps and institutional affiliations.
Ready to submit your research? Choose BMC and benefit from:

- fast, convenient online submission

- thorough peer review by experienced researchers in your field

- rapid publication on acceptance

- support for research data, including large and complex data types

- gold Open Access which fosters wider collaboration and increased citations

- maximum visibility for your research: over $100 \mathrm{M}$ website views per year

At BMC, research is always in progress.

Learn more biomedcentral.com/submissions 